\title{
Increased winter precipitation benefits the native plant pathogen Ustilago bullata that infects an invasive grass
}

\author{
Janet S. Prevéy $\mathbb{D} \cdot$ Timothy R. Seastedt
}

Received: 4 January 2015/Accepted: 19 June 2015/Published online: 27 June 2015

(C) Springer International Publishing Switzerland 2015

\begin{abstract}
Ustilago bullata is a fungal pathogen that infects grasses in western North America. It infects the grass Bromus tectorum, sometimes at epidemic levels, and has been considered as a biocontrol agent in regions where $B$. tectorum is invasive. During a study of the effects of variation in precipitation on $B$. tectorum demography in Colorado, USA, we observed infection by $U$. bullata and recorded data on variation in infection rates among treatments receiving different amounts of winter precipitation. Over 3 years, increased winter precipitation was correlated with a higher prevalence of infection by $U$. bullata. In one of those years (2012), infection was associated with a $21 \%$ decrease in $B$. tectorum seed yield in plots that received supplemental winter precipitation. While $B$. tectorum may exhibit higher rates of growth and/or reproduction if winter precipitation increases, results of our pathogen surveys suggest that associated population increases could be moderated by increased rates of fungal infection. Our observations suggest that although invasive species may benefit from climate change, some pathogens may also benefit, and
\end{abstract}

J. S. Prevéy $(\square)$

Swiss Federal Institute for Forest, Snow and Landscape Research, Flüelastrasse 11, 7260 Davos Dorf, Switzerland e-mail: janet.prevey@gmail.com

\section{J. S. Prevéy · T. R. Seastedt}

Department of Ecology and Evolutionary Biology, University of Colorado, UCB 450, Boulder, CO 80309 , USA decrease success of invasive plant populations in the future. These results highlight the importance of both direct and interactive effects of climate change on success of invasive species.

Keywords Bromus tectorum - Cheatgrass - Climate change $\cdot$ Invasive species $\cdot$ Precipitation change

\section{Introduction}

Global climate change will affect the abundance and success of plant species (Dukes and Mooney 1999; Thuiller et al. 2007; Hellmann et al. 2008) and plant pathogens (Coakley et al. 1999; Pautasso et al. 2012; Chakraborty 2013). Further, changing climatic conditions may alter the frequency and intensity of biotic interactions between plants and pathogens (Garrett et al. 2006; Tylianakis et al. 2008). Infection by pathogens can have strong effects on plant growth (Van der Putten et al. 1993) and climate induced changes in the interactions between plants and pathogens can greatly affect plant success (Van der Putten and Peters 1997; Pautasso et al. 2012). While the effects of climate change on invasive plant species have been extensively considered (e.g. Hellmann et al. 2008; Dukes et al. 2011), relatively few studies have examined how invasive plants may interact with pathogen pressure in a changing climate (Tylianakis et al. 2008; Seastedt 2014). Increasing temperature and precipitation associated with climate change may 
benefit invasive plants more than native ones, at least in portions of North American rangelands (Zelikova et al. 2013; Concilio et al., in press). However, the overall effects of global climate change on invasive plant populations could be strongly influenced by changing dynamics of plant/pathogen interactions.

Most research on plant pathogens and climate change concerns how success of crop pathogens will be influenced by changing climate (Coakley et al. 1999; Chakraborty et al. 2000). Another interesting, and less well-studied, impact of global change may be changes in success of pathogens on invasive species. Success of invasive plant species in new environments is often attributed to enemy release, or an escape from predators and pathogens in their home range (Klironomos 2002; Mitchell and Power 2003; Reinhart et al. 2003; Callaway et al. 2004). However, novel enemies in the new ranges can impact invasive plant abundance (Mack 1996; Parker and Gilbert 2004; Mitchell et al. 2006; Callaway et al. 2013). Changing climatic conditions have the potential to alter the abundance of both invasive plant species and novel enemies in the future.

Here, we report observational data on plant/pathogen interactions collected during a study examining the effects of increased precipitation on populations of an invasive plant. We designed a precipitation manipulation experiment to simulate changes in precipitation caused by climate change. We hypothesized that increased winter precipitation would benefit the invasive winter-annual Bromus tectorum (cheatgrass). After one year of manipulations, we observed the native fungal pathogen, Ustilago bullata, infecting seed heads of B. tectorum in our study plots. We decided to record presence and abundance of $U$. bullata to examine how simulated precipitation change would influence infection by the pathogen on an invasive grass.

Ustilago bullata is native to North America, and it infects several cool-season grass species, including the invasive B. tectorum (Stewart and Hull 1949; Mack and Pyke 1984; Gossen and Turnbull 1995). Spores of $U$. bullata germinate and develop into sporidia in soil, and fuse to create hyphae that infect grasses during the seedling stage. The pathogen grows systemically inside the host until flowering, when it entirely coopts seed production of the plant, causing it to produce spores of the fungus instead of viable seeds. These spores then disperse to the soil to repeat the cycle (Alexopoulos et al. 1996; Meyer et al. 2008). Introduced species, such as B. tectorum, did not evolve with, and may have less resistance to, native pathogens such as $U$. bullata, and thus may be more easily infected than native species (Mack 1996; Parker and Gilbert 2004; Verhoeven et al. 2009; Callaway et al. 2013). In the past, there have been instances where this pathogen has reached epidemic proportions, wiping out entire populations of B. tectorum (Stewart and Hull 1949; Klemmedson and Smith 1964; Mack and Pyke 1984). Because of this, and because it is native to North America, $U$. bullata has been suggested as a potential biocontrol mechanism for B. tectorum (Meyer et al. 2001, 2008). Observing how changing precipitation patterns affect $U$. bullata will inform considerations for use of this pathogen as a possible biocontrol in the future.

Pathogens that complete part of their life cycle in soil, such as $U$. bullata, may be particularly affected by changes in precipitation and soil moisture availability. Plant microbial pathogens, especially fungal pathogens, often benefit from increased soil moisture (Schafer and Kotanen 2003; Wagner and Mitschunas 2008). Studies show that adequate soil moisture influences the abundance of $U$. bullata (Mack and Pyke 1984; Meyer et al. 2008), so future changes in precipitation and soil moisture availability should impact success of the pathogen.

For 3 years, we recorded observations of the fungal pathogen in different precipitation treatments to address two questions: How does seasonality and amount of precipitation affect the abundance of $B$. tectorum infected by $U$. bullata? Does presence of the pathogen significantly reduce seed yield of the invasive grass $B$. tectorum in precipitation manipulation treatments?

\section{Methods}

Observations of infection by the fungal pathogen were made in a precipitation manipulation experiment at a site associated with a semi-arid grassland ecosystem near Boulder, Colorado, USA $\left(40^{\circ} 07^{\prime} \mathrm{N}, 105^{\circ} 18^{\prime} \mathrm{W}\right)$. The site has an elevation of $1798 \mathrm{~m}$, a mean annual precipitation of $475 \mathrm{~mm}$, and a mean annual temperature of $10.5{ }^{\circ} \mathrm{C}$ (WRCC 2014). The site has a 
continental climate, with most precipitation falling as rain in spring and early summer, and c.a. $26 \%$ of precipitation falling as snow over the winter (WRCC 2014). A precipitation manipulation experiment was established in 2010 with five precipitation manipulations: control, winter-wet, winter-wet/summer-dry, winter-wet/summer-wet, and winter-dry/summerwet. The winter and summer-dry treatments were accomplished using rain-out shelters that block $50 \%$ of incoming precipitation, and the winter and summer wet-treatments were accomplished with water additions from a local water source designed to increase precipitation $50 \%$ above ambient. There were ten replicates of each treatment. All plots of the experiment were located within 1 ha of each other, on the same slope and with similar soils. More information on the experimental design of the precipitation manipulations can be found in Prevéy and Seastedt (2014).

We measured prevalence of $U$. bullata in plots of all treatments in June 2011-2013, after all B. tectorum in plots had senesced. Infected plants produce black teliospores of $U$. bullata instead of seeds, and these remain on the plant after senescence. We visually inspected each plot for presence of the pathogen on seed heads of B. tectorum. In addition, we harvested six B. tectorum individuals per plot in June of 2011 and 2012 and eight individuals per plot in June of 2013 to quantify seed yield and infection status. Plants were collected at $0.25 \mathrm{~m}$ intervals along a transect running through the middle of each plot. We dried and weighed harvested plants, and then counted the number of seeds produced per individual and recorded the presence of infection by $U$. bullata.

In June 2012 and 2013 we also measured the proportion of $B$. tectorum infected with $U$. bullata within $0.1 \mathrm{~m}^{2}$ subplots in each treatment. Subplots were created in November 2011 to monitor demographic responses of $B$. tectorum to precipitation manipulations (Prevéy 2014). On November 15, 2011, $0.1 \mathrm{~m}^{2}$ subplots were disturbed to remove surface vegetation. Fifty $B$. tectorum seeds were sown in each subplot. On June 20, 2012, after all B. tectorum in subplots had senesced; we harvested aboveground biomass in subplots. Harvested B. tectorum were visually inspected for infection by $U$. bullata. On October 18, 2012, we planted another 50 seeds in each subplot, and on June 26, 2013, all B. tectorum was harvested from subplots and U. bullata infection was recorded.

\section{Statistical analyses}

We employed several analyses to examine how precipitation treatments affected abundance of $U$. bullata. First, we compared presence and absence of $U$. bullata in plots of each treatment in 2011-2013. Because the response variable was either presence or absence, we analyzed data with generalized linear models with binomial distributions. However, spatial heterogeneity in the presence of the pathogen in soil could result from factors other than precipitation treatment (Ettema and Wardle 2002), so only examining presence or absence data might not provide an accurate representation of the effects of precipitation timing and amount on pathogen prevalence. To evaluate the severity of infection in plots where we knew the pathogen was present, we performed correlation analyses that only included data from plots where we observed infection by the pathogen. We excluded plots in which infection was not observed and then calculated the average percent of B. tectorum infected with $U$. bullata among all plots in each precipitation treatment. To examine how winter precipitation might impact infection severity, we correlated the average percent of $B$. tectorum infected with $U$. bullata in each treatment in each year with the amount of winter precipitation received by that treatment in that year using linear models. We included percent cover of B. tectorum and average aboveground biomass of individual $B$. tectorum as covariates in initial correlation analyses. We performed correlation analyses for infection severity on transects in 2011-2013, and subplots in 2012-2013.

To determine if infection by $U$. bullata was negatively affecting the amount of seeds produced by $B$. tectorum at the field site, we examined the effects of pathogen infection on the average seed yield of B. tectorum in plots of each treatment in each year. We compared the average number of seeds per individual in each plot including B. tectorum with $U$. bullata infection (and thus no viable seeds), to the average number of seeds per individual excluding infected B. tectorum, to calculate the percent reduction in seed yield of B. tectorum per treatment, per year. All 
analyses were performed in the statistical program $\mathrm{R}$ (R Development Core Team 2012).

\section{Results}

Ambient winter precipitation varied over the 3 years of the study, with drier winters in 2010-2011 and 2012-2013, and a wetter than average winter in 2011-2012. Average winter temperatures were similar over the 3 years, although January 2012 was unseasonably warm (Fig. 1). There were no significant differences in presence of $U$. bullata between treatments in any year (all $p>0.3$, Fig. 2). Overall, $U$. bullata was present in only $26 \%$ of plots of all treatments in 2011, but was present in over $60 \%$ of all plots in 2012 and 2013 ( $p<0.02$ for comparisons of presence in 2011 to 2012 or 2013, Fig. 2).

Neither percent cover nor aboveground biomass of $B$. tectorum explained significant variation in severity of infection with $U$. bullata ( $p=0.33$ and $p=0.11$, respectively), so these variables were removed from final correlation analyses. Correlation coefficients for infection abundance in transects and subplots were similar (William's $t$ test, $p=0.41$ ), so we combined all measurements from transects and subplots for the correlation analysis. The percent of $B$. tectorum infected with $U$. bullata positively correlated with increasing winter precipitation in transects and subplots over the 3 years $\left(\mathrm{R}^{2}=0.25, p=0.01\right.$, Fig. 3$)$.

Across all plots in 2012 and 2013, infection with $U$. bullata was associated with a 3-4 \% reduction in mean seed yield (Fig. 4). Among treatment/year combinations, the largest reduction $(21 \%, p<0.0001)$ occurred

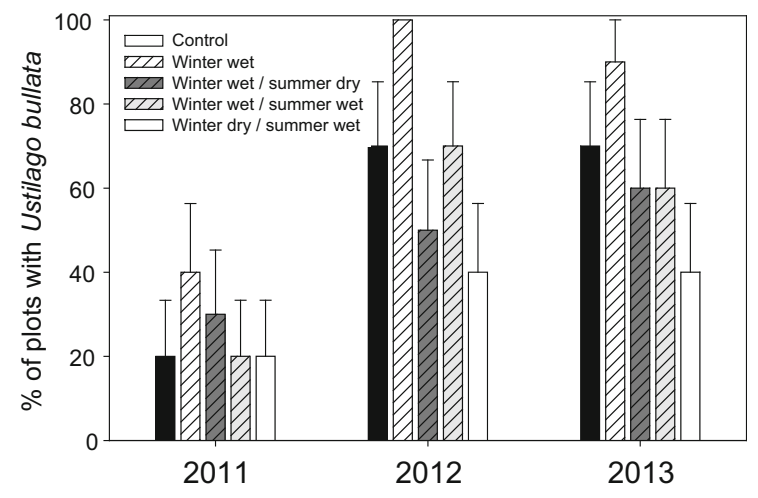

Fig. 2 Percent of plots in each precipitation treatment in which U. bullata was present in 2011-2013, +standard error

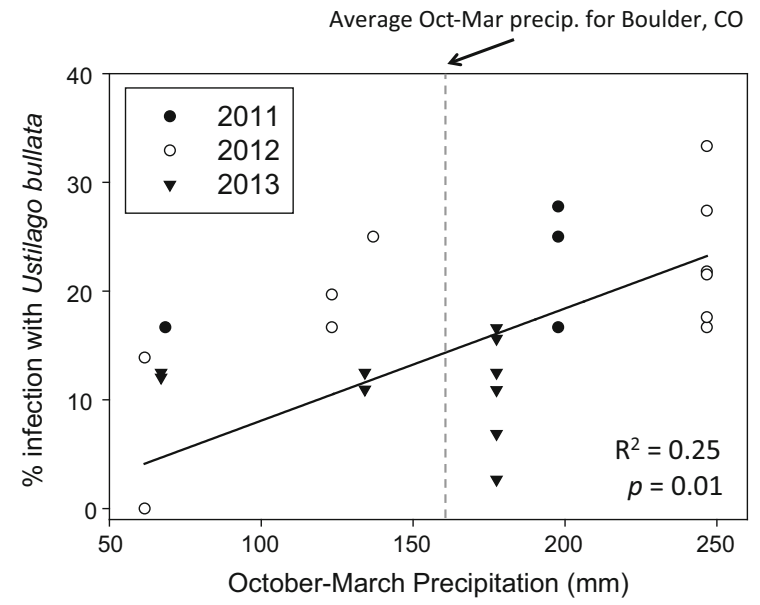

Fig. 3 Relationship between average percent of B. tectorum infected with $U$. bullata per treatment per year and cumulative precipitation received by that treatment from October to March. This analysis only includes plots where $U$. bullata was present
Fig. 1 Total precipitation received by each treatment in each month (bars) and average monthly temperature from September 2010 to June 2013 (red line). Dotted lines indicate the temperature range within which $U$. bullata is most successful at infecting seedlings (Boguena et al. 2007)

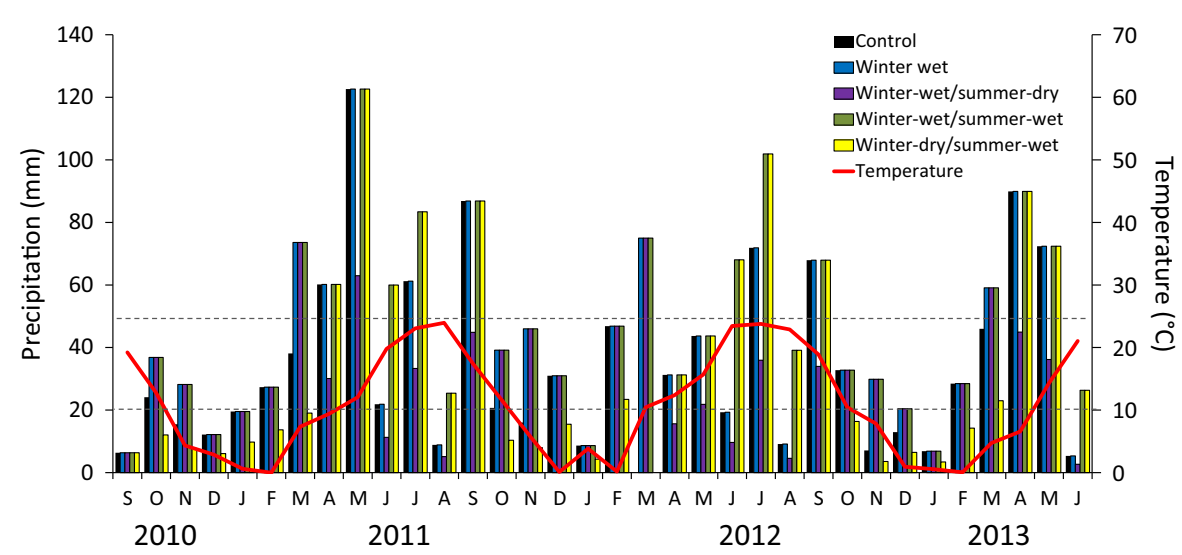




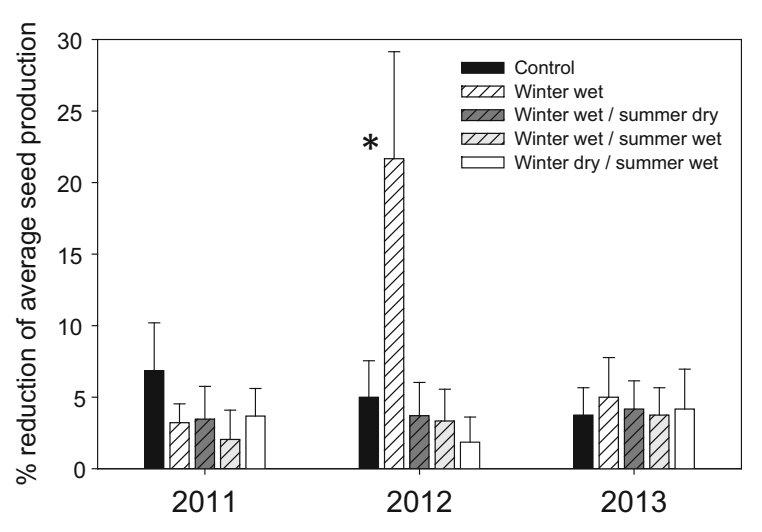

Fig. 4 Percent reduction in seed production resulting from $U$. bullata infection in precipitation treatments in 2011-2013, + standard error. Seed production was significantly reduced in winter wet treatments in 2012 compared to all other treatments $(p<0.0001)$

in plots experiencing the winter-wet treatment in 2012. There was no difference across treatments in the effect of $U$. bullata on seed set of B. tectorum, with the exception of the winter-wet treatment in 2012.

\section{Discussion}

Ambient winter precipitation and precipitation manipulation treatments affected rates of $U$. bullata infection observed in our study, and these effects may have important implications for the utility of $U$. bullata as a biocontrol in future climate scenarios. Increased winter precipitation was correlated with an increase in the abundance of $U$. bullata in plots. Notably, treatments that received above average winter precipitation had the highest rates of infection, indicating that increases in future mean winter precipitation could benefit $U$. bullata, all else being equal.

Winter-wet treatments in 2012 had the highest infection abundance both in the percentage of plots with $U$. bullata present and in the percentage of plants infected, and also received the most winter precipitation of all treatments in all years. The fungal pathogen may need adequate soil moisture to survive in soil and infect emerging seedlings in late fall (Meyer et al. 2008), so treatments receiving additional winter precipitation have higher infection rates, whereas those receiving winter drought have lower rates. In addition to a wet winter, January 2012 was also warmer than other years (Fig. 1), and warm temperatures might also benefit $U$. bullata. Ustilago bullata at our field site may be able to infect more seedlings during mild temperatures in fall and winter than in cold temperatures. Boguena et al. (2007) found that $U$. bullata is most successful at infecting seedlings at temperatures ranging from 20 to $30{ }^{\circ} \mathrm{C}$, and less successful in cold temperatures. Similar to our findings, Rua et al. (2014) observed that elevated temperature and precipitation led to increased infection of a non-native cool-season grass, Schedonorus arundinaceus, by viral pathogens in North America. In contrast, infection severity across treatments in 2013 was lower than the other years, even in treatments with supplemental winter precipitation. 2013 received the lowest winter precipitation of all years, and it is possible that experimental water additions did not alleviate dry periods between precipitation events in that year. Our results indicate that significantly higher than average winter precipitation may be needed to increase infection rates of $U$. bullata. Additionally, the high variability in presence and infection severity of $U$. bullata across treatments and years indicates that factors other than winter precipitation also influence abundance of this pathogen. Future experiments manipulating both temperature and the timing and quantity of precipitation will provide additional information on how climate influences success of $U$. bullata.

Overall, there were no differences across treatments in the effect of $U$. bullata on plot-level seed yield, and infection by $U$. bullata did not substantially lower average seed yield of B. tectorum. However, in 2012, seed set in winter-wet plots receiving greater than $250 \mathrm{~mm}$ of winter precipitation was reduced by over $20 \%$. Reducing seed yield by over $20 \%$ could reduce propagule pressure and slow population growth of this invasive grass. Over the past 121 years, winter precipitation near the study area was greater than $200 \mathrm{~mm}$ in $20 \%$ of the years, and greater than 250 in $8 \%$ of the years (WRCC 2014). With an increasing probability of more winter precipitation along the Front Range of Colorado in the future (Knowles et al. 2006; Ray et al. 2008; IPCC 2013), U. bullata may become more abundant. Bromus tectorum does not form a long-lived seedbank (Smith et al. 2008), and pandemic levels of $U$. bullata can eliminate entire populations of B. tectorum from the landscape (Mack and Pyke 1984; Stewart and Hull 1949).

Additional research focusing on the mechanistic reasons for success of $U$. bullata in different 
precipitation scenarios is needed to understand how this pathogen will respond to climate change. Experiments testing the effects of different pathogen strains, winter temperatures, and plant resistance genotypes on success of infection will help inform the use of $U$. bullata as a biocontrol in the future. However, our results provide preliminary evidence that increased winter precipitation, and possibly warmer autumn temperatures, could benefit the pathogen $U$. bullata. Higher infection rates of $U$. bullata in the future may decrease abundance of the invasive grass B. tectorum. Most climate manipulation experiments focus on responses of individual species, or trophic levels, to climate manipulations, but interactions between trophic levels will influence responses of species to climate change as well (Tylianakis et al. 2008; Van der Putten et al. 2010). The observations of increased infection of B. tectorum by $U$. bullata in this climate manipulation experiment have important implications for interactions between invasive plant species and pathogens. Many invasive plants may become more successful as the climate changes; however, some pathogens may also benefit, and decrease success of invasive plants in the future.

Acknowledgments Funding for this research was provided by an US Environmental Protection Agency STAR Graduate fellowship to J.S.P. We thank Melinda Sullivan for help with initial identification of Ustilago bullata, and Yuri Springer and Daniel Preston for thoughtful conversations about plant pathogens and precipitation. We also thank Yuri Springer, along with William Bowman, Sharon Collinge, Nichole Barger, and two anonymous reviewers for providing helpful comments on an earlier draft of this manuscript.

\section{References}

Alexopoulos CJ, Mims CW, Blackwell M (1996) Introductory mycology, 5th edn. Wiley, New York

Boguena T, Meyer SE, Nelson DL (2007) Low temperature during infection limits Ustilago bullata (Ustilaginaceae, Ustilaginales) disease incidence on Bromus tectorum (Poaceae, Cyperales). Biocontrol Sci Tech 17:33-52

Callaway RM, Thelen G, Rodriguez A, Holben WE (2004) Soil biota and exotic plant invasion. Nature 427:731-733

Callaway RM, Montesinos D, Williams K, Maron JL (2013) Native congeners provide biotic resistance to invasive Potentilla through soil biota. Ecology 94:1223-1229

Chakraborty S (2013) Migrate or evolve: options for plant pathogens under climate change. Glob Change Biol 19:1985-2000

Chakraborty S, Tiedemann AV, Teng PS (2000) Climate change: potential impact on plant diseases. Environ Pollut 108:317-326
Coakley SM, Scherm H, Chakraborty S (1999) Climate change and plant disease management. Annu Rev Phytopathol 37:399-426

Concilio AL, Prevéy JS, Omasta P, O’Conner J, Nippert JB, Seastedt TR (in press) Response of a mixed grass prairie to an extreme precipitation event. Ecosphere

Dukes JS, Mooney HA (1999) Does global change increase the success of biological invaders? Trends Ecol Evol 14:135-139

Dukes JS, Chiariello NR, Loarie SR, Field CB (2011) Strong response of an invasive plant species (Centaurea solsitialis L.) to global environmental changes. Ecol Appl 21:18871894

Ettema CH, Wardle DA (2002) Spatial soil ecology. Trends Ecol Evol 17:177-183

Garrett KA, Dendy SP, Franks EE, Rouse MN, Travers SE (2006) Climate change effects on plant disease: genomes to ecosystems. Annu Rev Phytopathol 44:489-509

Gossen BD, Turnbull GD (1995) Head smut (Ustilago bullata) of grasses on the Canadian prairies: distribution, impact, and control. Can J Plant Pathol 17:49-56

Hellmann JJ, Byers JE, Bierwagen BG, Dukes JS (2008) Five potential consequences of climate change for invasive species. Conserv Biol 22:534-543

IPCC (2013) Climate Change 2013: The Physical Science Basis. Contribution of Working Group I to the Fifth Assessment Report of the Intergovern-mental Panel on Climate Change. In: Stocker TF, Qin D, Plattner GK, Tignor M, Allen SK, Boschung J, Nauels A, Xia Y, Bex V, Midgley PM (eds) Cambridge University Press, Cambridge. http:// www.ipcc.ch/report/ar5/wg1/

Klemmedson JO, Smith JG (1964) Cheatgrass (Bromus tectorum L.). Bot Rev 30:226-262

Klironomos JN (2002) Feedback with soil biota contributes to plant rarity and invasiveness in communities. Nature 417:67-70

Knowles N, Dettinger MD, Cayan DR (2006) Trends in snowfall versus rainfall in the western United States. J Clim 19:4545-4559

Mack RN (1996) Biotic barriers to plant naturalization. In: Proceedings of the IX international symposium on biological control of weeds, pp 39-46

Mack RN, Pyke DA (1984) The demography of Bromus tectorum: the role of microclimate, grazing, and disease. J Ecol 72:731-748

Meyer SE, Nelson DL, Clement S (2001) Evidence for resistance polymorphism in the Bromus tectorum-Ustilago bullata pathosystem: implications for biocontrol. Can J Plant Pathol 23:19-27

Meyer SE, Nelson DL, Clement S, Beckstead J (2008) Cheatgrass (Bromus tectorum) biocontrol: using indigenous fungal pathogens. USDA Forest Service Proceedings RMRS-P-52

Mitchell CE, Power AG (2003) Release of invasive plants from fungal and viral pathogens. Nature 421:625-627

Mitchell CE, Agrawal AA, Bever JD et al (2006) Biotic interactions and plant invasions. Ecol Lett 9:726-740

Parker IM, Gilbert GS (2004) The evolutionary ecology of novel plant-pathogen interactions. Annu Rev Ecol Evol Syst 35:675-700

Pautasso M, Döring TF, Garbelotto M, Pellis L, Jeger MJ (2012) Impacts of climate change on plant diseases-opinions and trends. Eur J Plant Pathol 133:295-313 
Prevéy JS (2014) Precipitation change in a semi-arid grassland: plant community responses and management strategies. Dissertation, University of Colorado at Boulder

Prevéy JS, Seastedt TR (2014) Seasonality of precipitation interacts with exotic species to alter composition and phenology of a semi-arid grassland. J Ecol 102:1549-1561. doi:10.1111/1365-2745.12320

Ray AJ, Barsugli JJ, Averyt KB et al (2008) Climate change in Colorado. A report to the Colorado Water Conservation Board. Colorado Water Conservation Board. http://wwa. colorado.edu/publications/reports/WWA_ClimateChange ColoradoReport_2008.pdf

Reinhart KO, Packer A, Van der Putten WH, Clay K (2003) Plant-soil biota interactions and spatial distribution of black cherry in its native and invasive ranges. Ecol Lett 6:1046-1050

Rua MA, McCulley RL, Mitchell CE (2014) Climate drivers, host identity, and fungal endophyte infection determine virus prevalence in a grassland ecosystem. J Ecol 102:690-699

Schafer M, Kotanen PM (2003) The influence of soil moisture on losses of buried seeds to fungi. Acta Oecol 24:255-263

Seastedt TR (2014) Biological control of invasive plant species: a reassessment for the Anthropocene. New Phytol 205:490-502

Smith DC, Meyer SE, Anderson VJ (2008) Factors affecting Bromus tectorum seed bank carryover in western Utah. Rangeland Ecol Manag 61:430-436

Stewart G, Hull AC (1949) Cheatgrass (Bromus tectorum L.) an ecologic intruder in Southern Idaho. Ecology 30:58-74

R Development Core Team (2012) R: a language and environment for statistical computing. R Foundation for Statistical
Computing, Vienna, Austria. ISBN:3-900051-07-0, URL: http://www.R-project.org/

Thuiller W, Richardson DM, Midgley GF (2007) Will climate change promote alien plant invasions? Biological invasions. Ecological studies, vol 193. Springer, Berlin, pp 197-211

Tylianakis JM, Didham RK, Bascompte J, Wardle DA (2008) Global change and species interactions in terrestrial ecosystems. Ecol Lett 11:1351-1363

Van der Putten WH, Peters BAM (1997) How soil-borne pathogens may affect plant competition. Ecology 78 : 1785-1795

Van der Putten WH, Dijk CV, Peters BAM (1993) Plant-specific soil-borne diseases contribute to succession in fordune vegetation. Nature 362:53-55

Van der Putten WH, Macel M, Visser ME (2010) Predicting species distribution and abundance responses to climate change: why it is essential to include biotic interactions across trophic levels. Phil Trans R Soc B 365:2025-2034

Verhoeven KJ, Biere A, Harvey JA, Van Der Putten WH (2009) Plant invaders and their novel natural enemies: who is naive? Ecol Lett 12:107-117

Wagner M, Mitschunas N (2008) Fungal effects on seed bank persistence and potential applications in weed biocontrol: a review. Basic Appl Ecol 9:191-203

WRCC (2014) Western Regional Climate Center: Climate summary for Boulder, Colorado. http://www.wrcc.dri.edu/ cgi-bin/cliMAIN.pl?co0848

Zelikova TJ, Hufbauer RA, Reed SC, Wertin T, Fettig C, Belnap J (2013) Ecol Evol 3:1374-1387 